\author{
Marek Ziarko \\ Zespół Szkół \\ w Świątnikach Górnych \\ Sławomir Dorocki \\ Uniwersytet Pedagogiczny \\ im. Komisji Edukacji Narodowej \\ w Krakowie
}

Rose Boutron

Collège Robert Goupil

w Beaugency

\title{
Planowanie kariery zawodowej w procesie ksztalcenia we Francji
}

\section{Planning a professional career in the educational process in France}

\section{Streszczenie}

Celem pracy jest przedstawienie doświadczeń francuskiej edukacji w zakresie przygotowania uczniów do wyboru zawodu. W tekście zaprezentowano główne działania podejmowane na szczeblu szkoły średniej (école secondaire), na poziomie collège. Na tym etapie uczeń wybiera dalszą ścieżkę edukacyjną. Doradztwo oraz planowanie kariery zawodowej ma we Francji bardzo bogatą tradycję, sięgającą początków XX w. Jednakże dopiero ustawa o edukacji z lipca 1989 r. narzuciła szkole obowiązek prowadzenia poradnictwa i informacji na temat edukacji i pracy zawodowej. Z kolei ustawa o poradnictwie zawodowym z kwietnia 2005 r. zobowiązała szkoły do opracowania własnego projektu edukacyjnego w zakresie poradnictwa zawodowego. W projekt ten - obok szkoły i nauczycieli - powinni być zaangażowani rodzice uczniów, doradcy zawodowi, tzw. conseiller d'orientation, i profesjonaliści z samorządu lokalnego, organizacji branżowych, firm i stowarzyszeń. Organizacjami pomocnymi w wyborze zawodu są także: Krajowa Agencja Pracy (Pôle Emploi), Centrum Informacji i Dokumentacji Młodzieżowej CIDJ (Centre d'Information et de Documentation Jeunesse), Krajowe Biuro Informacji o Kształceniu i Zawodach ONISEP (Office National d'Information sur les Enseignements et les Professions) czy Centrum Studiów i Badań Kwalifikacji Zawodowych CEREQ (Centre d'Etudes et de Recherches sur les Qualifications). W procesie szkolnym wszyscy uczniowie gimnazjum i liceum uczestniczą w programie edukacyjnym, tzw. ścieżce odkrywania drogi zawodowej i edukacyjnej, którego celem jest przedstawienie w miarę szerokiego spektrum dostępnych zawodów oraz dróg kształcenia. Na etapie gimnazjum wspomniana ścieżka jest jednym ze sposobów nabywania wiadomości i kompetencji wspólnych każdej aktywności zawodowej - mowa tu o kompetencjach społecznych i obywatelskich oraz takich cechach, jak niezależność i inicjatywa. Na etapie liceum ścieżka odkrywania drogi zawodowej i edukacyjnej jest kontynuowana i dostosowana do założeń reformy liceów, która weszła w życie w roku szkolnym 2010. W ramach tzw. nowego liceum do dyspozycji ucznia oddano nowe narzędzia: wsparcie spersonalizowane (accompagnement personnalisé, dwie godziny zajęć tygodniowo), mentoring i możliwości korygowania obranej drogi edukacyjnej. Wprowadzenie do programu ostatniej klasy collège opcji odkrywanie zawodów (DP3) w roku szkolnym 2005 było odpowiedzią na coraz bardziej widoczne nieprzystosowanie młodych ludzi do realiów rynku pracy, wynikające z niewystarczającego przygotowania ich na ten ważny w drodze do niezależności i samorealizacji krok. Należy stwierdzić, że chociaż francuska oświata 
względnie późno zorientowała się w usterkach systemu na linii szkoła - praca, podjęte zostały dość szeroko zakrojone, wszechstronne działania mające tę sytuację poprawić. Za wcześnie jeszcze, by oceniać, na ile reforma z 2005 r. okaże się skuteczna, ale liczba różnych działań i inicjatyw na rzecz zwiększenia świadomości ekonomicznej wśród młodzieży oraz lepszego przygotowania jej do podjęcia pracy zawodowej daje dobry wzór dla innych krajów.

\begin{abstract}
The aim of this study is to provide insight into the experiences of the French education system in preparing students for making career choices. The text focuses on the key steps taken when students enter secondary school (école secondaire) at the junior level of high school (college). This is when young people have the opportunity to choose which path of education they will follow next.

Vocational guidance and planning in France has a very rich tradition, dating back to the beginning of the $20^{\text {th }}$ century. However, it was only the Education Act of July 1989 that placed schools under an obligation to provide information as well as educational and career guidance. Then, the Act of April 2005 on vocational guidance made it compulsory for each school to develop its own educational project on vocational guidance. The project aims to involve not only the school and teachers, but also the students' parents, career advisors, known as conseiller d'orientation, as well as professionals, with the assistance of the local authorities, trade organisations, companies and associations. Other organisations, whose role is to assist in the selection of a vocational career are the National Employment Agency (Pôle Emploi), the Centre of Information for Youth - CIDJ (Centre d'Information et de Documentation Jeunesse), the National Office for Education and Career Information - ONISEP (Office National d'Information sur les Enseignements et les Professions), and the Centre for Studies and Research on Qualifications - CEREQ (Centre d'Etudes et de Recherches sur les Qualifications). All students at junior and senior secondary level participate in an educational program called the "Pathway to the discovery of educational and vocational options", which aims to set forth a fairly comprehensive range of available professions and educational alternatives. At the junior secondary level, the above-mentioned pathway is one way of gaining knowledge and skills common to all types of professional activity, i.e. social and citizenship skills, as well as qualities such as independence and initiative. At the senior level, the "Pathway to the discovery of educational and vocational options" is continued and adjusted to comply with the objectives of the reform of senior secondary schools, implemented in 2010. All students of the "new senior secondary" school are to have new tools at their disposal: two hours per week of personalised assistance (accompagnement personalisé), mentoring and opportunities to review their current career path. The introduction, in 2005, of a new option called "discovering occupations" - DP3 - to the curriculum of the final year of collège was a response to the increasingly obvious maladjustment of young people to the realities of the job market, stemming from a lack of proper guidance prior to taking such an important step on the road to independence and self-fulfillment.

It must be said that, although French educational authorities were slow to note the existence of system faults at the school/work level of co-operation, they took quite far-reaching and comprehensive measures to rectify the situation. It is still too early to pass judgement on the effectiveness of the 2005 reform, however, the introduction of diverse actions and initiatives geared towards increasing economic awareness among young people and improved guidance enabling them to take up employment, are commendable and a worthy example for other nations.
\end{abstract}

Słowa kluczowe: doradztwo zawodowe; Francja; kształcenie; program; szkolnictwo

Keywords: career counseling; education; France; schools; teaching program

\title{
Wstęp
}

Na podstawie wyników europejskiego projektu FIFOBI prowadzonego w Niemczech, Polsce, Austrii, na Łotwie, w Portugalii, na Węgrzech i w Wielkiej Brytanii można zauważyć, 
że w opinii pracodawców oraz specjalistów od europejskiego rynku pracy absolwenci szkół nie są wyposażeni w tzw. kompetencje biznesowe związane z funkcjonowaniem w świecie biznesu i przygotowania do zawodu (Kurek, Rachwał, Szubert, 2012). Znaczenie kompetencji biznesowych jest ważne zarówno w aspekcie wchodzenia absolwentów szkół na rynek pracy czy rozwoju sektora małych i średnich przedsiębiorstw, jak i w rozwoju społeczno-gospodarczym układów przestrzennych różnej skali (m.in. Kurek, Rachwał, 2010, 2011; Naudé, 2008; Wach, 2007). Innym ważnym elementem kształcenia w aspekcie wejścia na rynek pracy jest planowanie kariery zawodowej. Potwierdzają to wyniki badań realizowanych w ramach projektu FIFOBI, w którym poddano analizie proces kształtowania kompetencji biznesowych (kształcenia przedzawodowego) w dwóch ostatnich latach obowiązkowej edukacji. Na podstawie badań ankietowych przeprowadzonych wśród polskich nauczycieli stwierdzono, że uczeń powinien umieć analizować kierunek dalszej nauki i kariery zawodowej w kontekście własnych predyspozycji i przez ocenę swoich możliwości. Potwierdza to tezę, że kształcenie w zakresie edukacji przedzawodowej na etapie gimnazjalnym jest niezwykle ważne, gdyż ten etap często decyduje o dalszej karierze zawodowej młodzieży. Dodatkowo, w kształceniu przedzawodowym konieczne jest obecnie odejście od teorii na rzecz realiów, przez likwidację bariery dzielącej edukację i rynek pracy w zakresie lokalnym i krajowym. Celem niniejszego artykułu jest przedstawianie miejsca planowania kariery zawodowej w procesie kształcenia we Francji w oparciu o plany i treści nauczania oraz zalecenia ministerstwa edukacji. Opisane doświadczenia francuskie stanowią przykład instytucjonalnej próby przygotowania młodzieży do wyboru zawodu oraz kształtowania postaw przedsiębiorczych. Omówione w tekście techniki i metody realizacji założeń edukacyjnych są - według autorów - atrakcyjne dla uczniów i godne odnotowania na gruncie polskiej edukacji.

Zagadnienia nauczania przedsiębiorczości oraz tematyka przygotowania młodzieży do wkroczenia na rynek pracy była podejmowana m.in. przez. Borowiec (2009), Brzegowego (2014), Dorockiego (2014), Kilar (2013), Kurek (2011), Oleksiuka (2013), Piróg (2005), Rachwała (2011), Wacha (2007) i Zioło (2012). Jednakże w tych opracowaniach tematyka planowania kariery zawodowej była ograniczona do krajowych doświadczeń lub szczebla akademickiego. W poniższym tekście autorzy starali się zapoznać czytelnika z najnowszymi działaniami podjętymi we francuskich szkołach średnich.

Artykuł w swym założeniu ma również stanowić podstawę do podjęcia dyskusji o przygotowaniu młodzieży do planowania własnej kariery zawodowej w Polsce.

\section{System szkolnictwa we Francji}

Podwaliny pod współczesny system edukacji we Francji położyła reforma Julesa Ferry’ego (1881-1882). Według jej założeń szkoła miała być obowiązkowa i bezpłatna, a także laicka, co oznaczało, iż przestrzeń szkolna oraz treści nauczania nie dopuszczały manifestowania symboli ani dogmatów religijnych. Zasady powszechności, bezpłatności i laickości systemu szkolnego obowiązują we francuskiej oświacie do dziś, a każde dziecko między 6. a 16. rokiem życia podlega obowiązkowi szkolnemu. Wyjątkiem laickości systemu szkolnego jest Alzacja i Lotaryngia, w których w wyniku uwarunkowań historycznych religia jest obecna w szkołach państwowych.

Znacząca większość szkół we Francji podlega bezpośredniej kontroli francuskiego Ministerstwa Edukacji Narodowej (Ministère de l'Éducation Nationale, de la Jeunesse et de la Vie associative, MENJVA). Również szkoły prywatne w większości działają w ramach kontraktu z MENJVA, co oznacza, że muszą się dostosować do jego dyrektyw oraz oficjalnych programów nauczania. Pozostałe szkoły prywatne, niezwiązane kontraktem, obejmują znikomy odsetek 
dzieci w wieku szkolnym. We Francji dopuszczalne jest również nauczanie w domu, ale są to marginalne przypadki. System szkolnictwa jest bardzo scentralizowany. Dyplomy wydawane przez szkoły są oparte na programach wspólnych dla wszystkich placówek, toteż są uznawane na wszystkich krajowych szczeblach edukacji. Również rekrutacja nauczycieli odbywa się na szczeblu centralnym: za pośrednictwem specjalnych instytucji kształcących nauczycieli - dla szkół podstawowych - oraz w drodze konkursu lub przydziału (affectation) po zdaniu państwowego egzaminu zwanego agrégation - dla szkół średnich.

W szkole podstawowej (école élémentaire) dziecko 6-letnie wkracza na pierwszy stopień kształcenia, trwający pięć lat. Na ten pierwszy etap nauki składają się: kurs przygotowawczy (cours préparatoire), kurs podstawowy (cours élémentaire, dwa poziomy) oraz kurs średni (cours moyen, dwa poziomy). W trakcie tych kursów dziecko uczy się czytać - dzięki lekturze tekstów, pisać - na zajęciach z redagowania tekstu, oraz liczyć - nabywając podstaw arytmetyki. Dziecko ma także styczność z językiem obcym, zazwyczaj angielskim, oraz informatyką. Zajęcia ze wszystkich przedmiotów zwykle są prowadzone przez tego samego nauczyciela.

Kolejny stopień to szkoła średnia (école secondaire), podobnie jak w Polsce podzielona na dwa poziomy, zwane we Francji cyklami. Cykl pierwszy to collège - odpowiednik naszego gimnazjum. Collège przyjmuje dzieci 11-letnie, a nauka w nim trwa cztery lata. Z przejściem ze szkoły podstawowej do collège nie są związane żadne egzaminy. Wspomnieć należy, iż we Francji obowiązuje numeracja lat szkolnych odwrotna niż w Polsce - jest ona malejąca, toteż uczeń collège rozpoczyna naukę w klasie szóstej, a kończy w trzeciej. Na tym etapie poszczególne kursy są już wyodrębnione. Są to: język francuski, matematyka, historia-geografia, wychowanie obywatelskie, nauki o życiu i ziemi, technologia, sztuki plastyczne, języki obce, wychowanie muzyczne, wychowanie fizyczne i sportowe, fizyka-chemia. Nauczają nauczyciele wyspecjalizowani w danej dziedzinie. Cykl pierwszy kończy się egzaminem i otrzymaniem dyplomu zwanego brevet. Na tym etapie uczeń ma możliwość wyboru dalszej ścieżki edukacyjnej. Drugi cykl, czyli liceum (lycée), obejmuje trzy klasy: drugą, pierwszą oraz końcową. We Francji wyróżnia się dwa typy liceów: liceum profilowane (ogólnokształcące i techniczne) oraz liceum zawodowe. W pierwszym przypadku po pierwszym roku nauki uczeń dokonuje wyboru pomiędzy ścieżką ogólną bądź technologiczną, a jego nauka kończy się egzaminem maturalnym (baccalauréat) o orientacji ogólnej lub technologicznej. Z kolei licea zawodowe (lycée professionnel) dają możliwość uzyskania dyplomu technika danej specjalności już po zaledwie roku lub dwóch latach nauki - jest to tzw. Certyfikat Kwalifikacji Zawodowych CAP (Certificat d'aptitude professionnelle) albo Dyplom Szkolenia Zawodowego BEP (Brevet d'enseignement professionnel). Nauka może trwać także trzy lata i kończy się maturą zawodową (baccalauréat professionnel) - dyplom ten poświadcza nabycie wysokich kwalifikacji zawodowych. Większość francuskich licealistów wybiera opcję maturalną, jest ona bowiem punktem wyjścia do dalszego kształcenia na uniwersytecie lub w którejś z prestiżowych wielkich szkół (Grandes Ecoles).

\section{Miejsce kursów planowania kariery zawodowej w szkole średniej we Francji}

Doradztwo i planowanie kariery zawodowej mają we Francji bardzo bogatą tradycję. W $1910 \mathrm{r}$. powstała w Paryżu instytucja informacji zawodowej (service d'information professionnelle), której celem miało być określanie uzdolnień dzieci i zapoznanie ich z perspektywami edukacyjnymi, mające na celu rozwijać ich talenty. W 1919 r. ustawą Astier stworzono biura orientacji zawodowej (offices d'orientation professionnelle) kierujące dzieci ze szkół podstawowych do nauki zawodu. Do 1930 r. oferta instytucji poradnictwa zawodowego była skierowana tylko do przyszłych pracowników fizycznych i biurowych. W 1928 r. został stworzony w Paryżu 
Krajowy Instytut Poradnictwa Zawodowego (Institut National d'Orientation Professionnelle), przekształcony w 1939 r. w Krajowy Instytut Badań nad Pracą i Poradnictwa Zawodowego (Institut national d'étude du travail et d'orientation professionnelle, INETOP). Instytut ten, podległy od 1941 r. Konserwatorium Sztuk i Profesji (Conservatoire National des Arts et Métiers) - najstarszej we Francji placówce o charakterze wyższej szkoły zawodowej - oferuje studia w zakresie nauk społecznych, psychologii poradnictwa i psychologii pracy oraz specjalizuje się w kształceniu przyszłych doradców zawodowych.

Świadomość, że edukacja nie może być oderwana od realiów rynku pracy, oraz przekonanie, że jednym z zadań szkoły jest również przygotowanie uczniów do podjęcia drogi zawodowej, znalazły swój wyraz we francuskim ustawodawstwie. Ustawa o edukacji z lipca 1989 r. głosi, iż „częścią prawa do kształcenia jest prawo do poradnictwa i informacji na temat edukacji i pracy zawodowej”. Z kolei ustawa o poradnictwie z kwietnia 2005 r. zakłada, że szkoły „opracowują [...] swój projekt edukacyjny i poradnictwa zawodowego przy pomocy rodziców, nauczycieli, doradców i innych kompetentnych profesjonalistów. Przyczynia się do tego odpowiednia administracja, samorząd lokalny, organizacje branżowe, firmy i stowarzyszenia". Oba te akty stanowią, że oświata jest priorytetem narodowym, wskazując jednocześnie na konieczność przygotowania dla każdego ucznia indywidualnego planu rozwoju edukacyjno-zawodowego.

Wśród celów narodowej polityki w zakresie poradnictwa zawodowego wymienia się m.in. umiejętność znalezienia własnej drogi rozwoju zawodowego w kształceniu podstawowym. Zadanie to realizowane jest dzięki większej indywidualizacji wsparcia zawodowego oraz lepszej jakości i dostępności świadczonych usług doradczych, a także dzięki przekazywaniu rzetelnych informacji na temat trendów na rynku pracy i podejmowaniu konkretnych działań zapobiegających wykluczaniu grup docelowych, takich jak młodzież z problemami w nauce lub ze środowisk społecznie upośledzonych. Kładzie się także większy nacisk na zwiększanie świadomości społecznej podmiotów społecznych w kwestii poradnictwa, w kontekście uczenia się przez całe życie - weryfikacja umiejętności i doświadczenia zawodowego osób dorosłych, kształcenie ustawiczne. Uznaje się, że „wybór własnej ścieżki kariery nie jest wyłącznie problemem ucznia, młodego człowieka czy nawet jego rodziny. Jest to także akt, którego konsekwencje mają wyraźnie społeczny charakter. Jednym z takich społecznych kontekstów decyzji o dalszej drodze edukacji, a w dalszej perspektywie funkcjonowania w określonej roli zawodowej, jest wpływ, jaki ma - lub może mieć - na nią szkoła. Dlatego okres pobytu w szkole powinien być przez uczniów wykorzystany na zdobycie informacji o różnych zawodach i ich wymaganiach, na odkrycie własnych możliwości, ustalenie celów na przyszłość oraz uświadomienie sobie swoich słabych stron, ewentualnych ograniczeń czy braków" (Dziewulak, 2013).

Za świadczenie usług i poradnictwo na rzecz młodzieży w szkołach średnich i wyższych odpowiedzialne są Ministerstwo Edukacji Narodowej (MENJVA) oraz Ministerstwo Szkolnictwa Wyższego i Badań Naukowych (Ministère de l'Enseignement Supérieur et de la Recherche Scientifique, MESRS). Większość usług związanych z doradztwem i pośrednictwem zawodowym, leżących w gestii Ministerstwa Edukacji Narodowej, jest świadczona w szkołach, które są odpowiedzialne za monitorowanie wszystkich uczniów w pierwszym roku po ukończeniu nauki, w Centrach Informacji i Poradnictwa (Centre d'informatiom et d'orientation, CIO) oraz ich agencjach podległych temu ministerstwu.

Orientacja szkolno-zawodowa (orientation scolaire et professionnelle) polega na zaproponowaniu uczniom różnych ścieżek zawodowych, które mogą podjąć w zależności od zainteresowań, wyników w nauce oraz cech osobowościowych. Liczne parametry pozwalające ustalić predyspozycje danej osoby mogą zostać określone dzięki testom psychometrycznym, kwestionariuszom lub testom projekcyjnym. Metod jest wiele i muszą się one opierać przede 
wszystkim na swobodzie wyboru zainteresowanej osoby. Celem jest osiągnięcie przez ucznia lepszego samozrozumienia, a dzięki temu doprowadzenie go do podejmowania właściwych decyzji zawodowych.

Osobą zajmującą się we Francji doradztwem zawodowym jest doradca zawodowy, tzw. conseiller d'orientation, lub nauczyciel, który przeszedł odpowiednie przeszkolenie w zakresie doradztwa. Od 1991 r. doradca zawodowy musi mieć wykształcenie psychologiczne, stąd też często stosuje się określenie psycholog doradztwa zawodowego (conseiller d'orientation-psychologue, CO-P). Doradcy pracują głównie w placówkach edukacyjnych oraz w CIO. Pomagają oni młodym ludziom w podejmowaniu decyzji dotyczących przyszłej pracy i przygotowania do niej. Dostarczają uczniom i rodzicom dodatkowe informacje na poziomie regionalnym, ogólnokrajowym, europejskim i światowym, dotyczące rynku pracy, trendów rozwojowych na świecie, zawodów i zatrudnienia, wykorzystania posiadanych uzdolnień i talentów. Ich zadania w szkołach średnich i wyższych są bardzo różne. Najważniejsze z nich to:

- gromadzenie, opracowywanie i aktualizowanie informacji o zawodach lub stanowiskach pracy, instytucjach kształcenia zawodowego oraz możliwościach uzyskiwania kwalifikacji, jak również o potrzebach rynku pracy,

- systematyczne monitorowanie uczniów, przyczyniające się do stworzenia warunków sprzyjających osiąganiu sukcesów,

- informowanie uczniów, studentów i ich rodzin o procedurach orientacyjnych, instytucjach edukacyjnych i ścieżkach zawodowych,

- prowadzenie indywidualnego poradnictwa wobec uczniów, studentów i ich rodziców,

- przeprowadzanie zajęć pozwalających na ewaluację uczniów i studentów,

- prowadzenie zajęć aktywizujących, przygotowywanie młodzieży do świadomego planowania kariery zawodowej,

- pomoc uczniom i studentom w realizacji projektów szkolnych i zawodowych,

- doradztwo techniczne dla dyrektora placówki i grona pedagogicznego w zakresie przygotowania działań dydaktycznych zorientowanych na poradnictwo,

- współuczestnictwo w działaniach prowadzonych przez innych członków grona pedagogicznego (www.education.gouv.fr).

Obecnie francuski system charakteryzuje duża różnorodność służb świadczących usługi w zakresie informacji i poradnictwa. Zaletą tej sytuacji jest szeroka gama technik, praktyk oraz osób wykonujących powyższy zawód w całym kraju. Oprócz samych szkół i wspomnianych Centrów Informacji i Poradnictwa, we Francji działa bardzo wiele instytucji publicznych, półprywatnych i prywatnych oferujących porady, wsparcie i ukierunkowanie w zakresie budowy własnej ścieżki zawodowej, wspierających i uzupełniających działalność informacyjno-poradniczą realizowaną przez doradców szkolnych. Warto wymienić chociażby Krajową Agencję Pracy (Pôle Emploi), Centrum Informacji i Dokumentacji Młodzieżowej (CIDJ) (Centre d'Information et de Documentation Jeunesse), Krajowe Biuro Informacji o Kształceniu i Zawodach (ONISEP) (Office National d'Information sur les Enseignements et les Professions) czy Centrum Studiów i Badań Kwalifikacji Zawodowych (CEREQ) (Centre d'Etudes et de Recherches sur les Qualifications). Celem tego ostatniego jest prowadzenie badań i analiza rynku pracy, zatrudnienia i realizowanych szkoleń. CEREQ przygotowuje i opracowuje materiały na temat bieżącej i przewidywanej sytuacji rynkowej w obszarze zapotrzebowania na konkretne zawody. Informacje przekazywane są następnie do ONISEP, który rozpowszechnia je wśród zainteresowanych uczniów i nauczycieli kształcenia zawodowego (Dziewulak, 2013). 


\section{Odkrywanie zawodów i orientacja aktywna}

Wybór zawodu jest dziś rozumiany jako proces, ciąg decyzji, który zaczyna się we wczesnym dzieciństwie i trwa przez całe życie. Ponieważ młody człowiek większą część swojego aktywnego czasu spędza w szkole, to właśnie ona powinna przygotować go wyboru zawodu i kierunku kształcenia. Za kluczowy okres w procesie orientacji uznaje się ostatni rok collège, kiedy to uczeń decyduje o wyborze szkoły średniej drugiego stopnia. Od liceum zaczyna się już bowiem kształcenie zawodowe, a młody człowiek musi być gotowy podjąć decyzję dotyczące swojej przyszłości. Dlatego też wszyscy uczniowie gimnazjum i liceum uczestniczą w programie edukacyjnym, tzw. ścieżce odkrywania drogi zawodowej i edukacyjnej (parcours de découverte des métiers et des formations), którego celem jest przedstawienie im w miarę szerokiego spektrum dostępnych zawodów oraz dróg kształcenia. Program ten pozwala uczniom m.in.:

- zrozumieć związek pomiędzy ich aktualną pracą na lekcjach a ścieżką edukacyjną, którą tworzą,

- poszerzyć ich horyzonty osobiste przez wyjście poza zakres profesji i wykształcenia, z którymi stykają się w rodzinie lub otoczeniu,

- umożliwić im nabycie wiadomości, umiejętności i nawyków przydatnych przez całe życie.

Program ten jest jednym z elementów zapobiegającym wczesnemu porzucaniu szkoły przez młodzież. Ponadto przyczynia się do wzmocnienia sektorów naukowych i technicznych oraz uczy poszanowania zasady równości szans. Krajowy program rozwoju szkół zdefiniowany w 2005 r. zakłada, że ścieżka odkrywania drogi zawodowej i edukacyjnej ma pozwolić podnieść poziom kwalifikacji w danym przedziale wiekowym: 100\% na pierwszym poziomie kwalifikacji, 80\% wśród maturzystów oraz u połowy absolwentów wyższych uczelni. Ścieżka jest opracowywana przez dyrektora placówki oświatowej przy udziale całego grona pedagogicznego, a przy jej tworzeniu wykorzystywane są wszelkie dostępne środki i materiały, m.in. dostarczone przez ONISEP i CIO, uniwersyteckie centrum informacji i poradnictwa SCUIO, misje lokalne, publiczne agencje ds. pracy i partnerów publicznych i prywatnych (Le parcours de découverte des métiers et des formations, www.education.gouv.fr).

Na etapie gimnazjum wspomniana ścieżka jest jedną z dróg nabywania wiadomości i kompetencji wspólnych dla każdej aktywności zawodowej. Są to zatem kompetencje społeczne i obywatelskie. Kształtowane są również wśród uczniów takie cechy, jak samodzielność i aktywność. Uczniowie zostają objęci ścieżką w drugim roku nauki - według nazewnictwa francuskiego jest to klasa piąta, cinquième. Wtedy też zaczyna się stopniowe prezentowanie im rozmaitych profesji oraz sposobów kształcenia. W pierwszym roku program obejmuje wizyty w przedsiębiorstwach i zakładach pracy oraz spotkania i wywiady z profesjonalistami z różnych dziedzin, pozwalające uczniom zapoznać się z wieloma zawodami i branżami. W roku drugim (klasa quatrième) uczniowie poznają istniejące drogi kształcenia - spędzają jeden dzień w liceum, Centrum Kształcenia Zawodowego (Centre de formation d'apprentis, CFA) lub innej placówce edukacyjnej. Trzeci rok programu przypada na ostatnią klasę gimnazjum (troisième). Wówczas przewiduje się m.in. „obserwację środowiska pracy zawodowej”. Każdy uczeń w trakcie nauki w gimnazjum spędza co najmniej 10 dni w jakimś przedsiębiorstwie. Wszyscy uczniowie odbywają również zindywidualizowane rozmowy orientacyjne.

Uczniowie mogą też skorzystać z opcji fakultatywnej odkrywania zawodów (découverte professionnelle) w wymiarze trzech lub sześciu godzin tygodniowo. Opcja fakultatywna trzygodzinna, tzw. DP3, jest narzędziem uzupełniającym kulturę ogólną uczniów i pogłębiającym znajomość świata zawodowego o aspekty ekonomiczne i społeczne. W żaden sposób nie warunkuje ona przyszłej orientacji uczniów. Uczniowie po zakończeniu gimnazjum mają pełną swobodę wyboru dalszej ścieżki kształcenia. Główne jej cele to: 
- poznanie zawodów: pokazanie uczniom, jak wygląda codzienna praca pilota, piekarza, webmastera czy pielęgniarki,

- poznanie środowiska pracy: jak zorganizowana jest praca w dużej lub małej firmie, w administracji, w laboratorium badawczym itp.,

- poznanie ścieżek kształcenia: jakie dyplomy można zdobyć, gdzie i jak można się do nich przygotować (szkolenia, przyuczanie do zawodu, kształcenie ustawiczne), gdzie można zasięgnąć potrzebnych informacji (CIO, ONISEP itd.).

Zajęcia w ramach DP3 są przygotowywane i prowadzone przez zespół animatorów z wielu dziedzin: nauczycieli gimnazjalnych i licealnych, doradców zawodowych itp. Mogą one obejmować m.in. wywiady i spotkania z profesjonalistami przedstawiającymi swój zawód lub ze starszymi uczniami i studentami opowiadającymi o swych wyborach edukacyjnych, wyszukiwanie informacji i analizę dokumentów, tworzenie raportów i dokumentacji na podstawie zebranych materiałów, wizyty, obserwacje i staże w przedsiębiorstwach w administracji, warsztatach, zakładach produkcyjnych oraz laboratoriach, a także tworzenie reportaży na temat zawodów, przedstawianie zdobytych doświadczeń na forum klasy, udział w panelach dyskusyjnych.

Kompetencje wyniesione z udziału w opcji DP3 są sprawdzane, a osiągnięte wyniki uwzględnione w dyplomie brevet. Opcja ta spotkała się z bardzo pozytywnym odzewem ze strony uczniów i ich rodziców, w rezultacie jest już obecna w ok. 80\% francuskich collège.

Moduł sześciogodzinny odkrywania zawodów, DP6, został skonstruowany w oparciu o te same zasady co opcja DP3, ale przewidziano w nim więcej czasu na poznanie środowiska zawodowego: przedsiębiorstwa, licea zawodowe lub też CFA. Jest on przeznaczony dla uczniów, którzy zdecydowali już, że po ukończeniu gimnazjum chcą podjąć naukę zawodu. Udział w DP6 ma im zatem pomóc $\mathrm{w}$ stworzeniu ich indywidualnego projektu (La découverte professionnelle en classe de troisième, www.education.gouv.fr/).

$\mathrm{Na}$ etapie liceum ścieżka odkrywania drogi zawodowej i edukacyjnej jest kontynuowana i dostosowana do założeń reformy liceów, która weszła w życie w roku szkolnym 2010. W ramach tzw. nowego liceum do dyspozycji ucznia oddano nowe narzędzia: wsparcie spersonalizowane (accompagnement personnalisé, dwie godziny zajęć tygodniowo), mentoring i możliwości korygowania obranej drogi edukacyjnej. Pierwsza klasa liceum (we Francji nazywana drugą, deuxième) to etap, kiedy uczeń określa swoje cele i wybiera interesujące go dziedziny wiedzy oraz powiązane $\mathrm{z}$ nimi metody. Jest w ten sposób wspomagany w ukierunkowaniu na wybór matury i studiów wyższych. Ma do dyspozycji dwie godziny tygodniowo wsparcia spersonalizowanego w celu opracowania projektu kształcenia i orientacji. W klasie drugiej (zwanej pierwszą, première) każdy uczeń spędza dzień na wyższej uczelni: uniwersytecie, w uniwersyteckim instytucie technologicznym (IUT), pomaturalnym studium technicznym (STS) lub studium przygotowującym do wielkich szkół (CPGE). Jest to początek przygotowania do orientacji aktywnej. W klasie końcowej (terminale) rada klasowa wydaje na koniec pierwszego trymestru swoją opinię i formułuje zalecenia odnośnie intencji ucznia w kwestii kształcenia pomaturalnego. Uczeń jest przygotowywany do orientacji aktywnej i otrzymuje pomoc przy procedurach związanych z wyborem uczelni oraz składaniem podań.

Orientacja aktywna to z kolei szereg działań informacyjnych, doradczych i towarzyszących, skierowanych do przyszłych maturzystów ze strony pracowników uniwersyteckich przy współudziale opiekunów klas i dyrektorów liceów. Działalność ta wpisuje się w kluczowe cele nowego liceum, które ma lepiej przygotowywać uczniów dzięki bardziej postępowym, otwartym i sprawiedliwym działaniom na rzecz wyboru ścieżki zawodowej. Pierwszym i najważniejszym punktem orientacji aktywnej jest informacja. Lepsza wiedza o treściach edukacyjnych, procentowej zdawalności na egzaminach czy szansach na zatrudnienie $\mathrm{w}$ danym zawodzie 
pozwala przyszłym studentom dokonać przemyślanych wyborów. Orientacja ta jest aktywna, ponieważ angażuje zarówno ucznia, jak i uniwersytet lub inną uczelnię wyższą w proces prowadzący do podjęcia decyzji: umacnia ucznia w jego pierwotnym wyborze bądź zaleca mu wybór kierunku albo sektora, w którym jego szanse będą największe. Dlatego też wśród oferowanych metod znaleźć można m.in. wymiany organizowane między liceami a wyższym uczelniami, pilotowane przez komisje kierowane przez rektorów. Aż do 2001 r. zajęcia te były skierowane do uczniów klasy maturalnej, którzy przygotowywali z rodzicami i opiekunami klas swoje plany kształcenia wyższego. Rada klasy, złożona z dyrektora, nauczycieli danej klasy, doradcy edukacyjnego oraz przedstawicieli uczniów i rodziców - która począwszy od pierwszego trymestru skupia szczególną uwagę na kwestii orientacji - wydaje opinię i zalecenia dla każdego ucznia, aby pomóc mu dokonać najodpowiedniejszego dla niego wyboru. Od roku szkolnego 2011 zajęcia te objęły także uczniów klasy première. Była to odpowiedź na oczekiwania uczniów, którzy potrzebowali informacji koniecznych do realizacji ich projektów rozwoju zawodowego. Można stwierdzić, że orientacja ta ma na celu antycypować przyszłe wybory uczniów. Wedle jej założeń każdy licealista, który chce kontynuować naukę na wyższej uczelni, powinien móc otrzymać przejrzyste i obiektywne informacje o całości oferty edukacyjnej oraz zindywidualizowane porady odnośnie sektora, który zamierzałby wybrać, jak też wszelkich stawianych przezeń wymagań. Ma też zostać przeszkolony w wyszukiwaniu informacji przydatnych w procesie podejmowania wyboru oraz procedur wstępnego zapisu na studia, który w przypadku większości wyższych uczelni odbywa się drogą elektroniczną, na specjalnie w tym celu utworzonej platformie (Orientation active: une aide individualisée pour les lycéens, www.education.gouv.fr).

\section{Inicjatywy i narzędzia wspierające szkoły w przygotowywaniu uczniów do podjęcia świa- domego i przemyślanego wyboru zawodu}

Wprowadzenie do programu ostatniej klasy collège opcji odkrywanie zawodów DP3 w roku szkolnym 2005 było odpowiedzią na coraz bardziej widoczne nieprzystosowanie młodych ludzi do realiów rynku pracy, wynikające z niewystarczającego przygotowania ich na ten ważny w drodze do niezależności i samorealizacji krok (Dorocki, Brzegowy, 2014a). Pomimo wprowadzenia do szkół średnich zajęć z doradcami zawodowymi, dysponującymi sporą gamą narzędzi i mającymi pomóc młodym ludziom określić ich predyspozycje i ukierunkować ich wybory, na jaw wyszła kolejna bolączka trapiąca przyszłe pokolenie pracowników: brak wiedzy o funkcjonowaniu współczesnej gospodarki. Od uczniów oczekuje się dokonania wyboru i wstąpienia na ścieżkę kształcenia, która doprowadziłaby ich do odnalezienia i zajęcia właściwego miejsca jako osoby pracującej - jednocześnie jednak ci młodzi ludzie niewiele wiedzą o tym, co właściwie czeka ich po ukończeniu kształcenia zawodowego. Nie wiedzą, jak funkcjonują firmy i przedsiębiorstwa ani jak wygląda codzienność w zawodzie, który zamierzają obrać. Nie wiedzą, czego pracodawcy mogą oczekiwać od nich, a czego oni mogą oczekiwać od pracodawców. Brakuje im nawet podstawowej wiedzy na temat funkcjonowania relacji zwierzchnik - podwładny w środowisku pracy. Zadaniem opcji DP3 ma być zatem uzdrowienie istniejącej sytuacji, ale należy wspomnieć, że stopniowe wypełnianie tej luki informacyjnej zaczęło się już pod koniec lat 90. poprzedniego stulecia, a inicjatorami zmiany były same przedsiębiorstwa.

Wśród prekursorów nowego podejścia była branża budowlana, długo uznawana za sektor, do którego trafiają młodzi ludzie, którzy nie mają jasnej wizji swojej przyszłości i właściwie nie do końca wiedzą, co chcą ani co potrafią robić. „Budowlanka” była kompromisem, wyborem niejako przymusowym - przecież coś trzeba było wybrać. Równocześnie taki przypadkowy wybór mógł się okazać trafny. Inicjatywa ze strony firm miała podłoże czysto pragmatyczne: 
w niedalekiej przyszłości niektóre branże czekała nieuchronna wymiana siły roboczej i zaistniała potrzeba przyciągnięcia nowych pracowników. Firmy zrozumiały, że to one muszą wyciągnąć rękę do młodych ludzi i wyjść do nich z atrakcyjną propozycją, a szkoła jest na to najlepszym miejscem. Rozliczne inicjatywy lokalne - głównie ze strony stowarzyszeń działających na rzecz przybliżenia szkoły ze środowiskiem pracy, takich jak Stowarzyszenie Młodzież i Przedsiębiorstwo (AJE - Association Jeunesse et Entreprise), pioniera w tej dziedzinie - mocno wsparły te działania. Niektóre wielkie firmy, np. Coca Cola, SFR czy Siemens, stworzyły nawet na użytek nauczycieli gimnazjalnych specjalne zestawy pedagogiczne, komiksy, płyty DVD itp. Za pośrednictwem Centrum Badań i Zasobów dla Nauczycieli Kształcenia Zawodowego CERPET ponad 1 tys. nauczycieli odbyło w 200 firmach partnerskich (Peugeot, McDonald’s, LaPoste, Nestlé, IKEA $\mathrm{i}$ in.) trzydniowe staże, mające lepiej ich przygotować do prowadzenia zajęć w ramach opcji DP3. Jedną z najaktywniejszych organizacji pozarządowych działających na tym polu jest 100000 Przedsiębiorców (100000 Entrepreneurs), stowarzyszenie założone w 2007 r. przez przedsiębiorcę Philippe Hayata (Dorocki, Brzegowy, 2014b). Działania stowarzyszenia skierowane są do młodzieży w wieku 13-25 lat, od gimnazjalistów po studentów, a ich celem jest przekazanie im kultury przedsiębiorczości podczas prezentacji i wykładów prowadzonych w placówkach oświatowych przez przedsiębiorców i szefów firm, których przeszkoliło stowarzyszenie. Dzięki takim spotkaniom młodzi ludzie zdobywają wiele przydatnych wiadomości o tym, jak działają przedsiębiorstwa różnych sektorów gospodarki, jakie problemy mogą napotkać i jak sobie z nimi radzić. Uczniowie dowiadują się, jak dostosowywać firmę do zmian w gospodarce, jak wyrobić sobie stabilną pozycję na rynku, jak pozyskiwać nowych klientów oraz dostają wiele innych informacji z zakresu ekonomii i przedsiębiorczości. Wszystkie wiadomości przekazane są w przejrzysty i ciekawy sposób, poparte przykładami zaczerpniętymi z doświadczeń prelegentów. Działania organizacji 100000 Przedsiębiorców objęły od 2007 r. ponad 200000 uczniów i studentów. Obecnie stowarzyszenie dysponuje siecią ponad 4,5 tys. partnerów przedsiębiorców i 3,5 tys. nauczycieli, organizując w ciągu roku szkolnego ok. 1850 spotkań. Zainteresowanie tą formułą okazało się tak wielkie, że zapotrzebowanie przekroczyło możliwości stowarzyszenia, które w rezultacie połączyło siły z Entreprendre pour Apprendre - zrzeszeniem 20 stowarzyszeń zorientowanych na promowanie przedsiębiorczości wśród młodych ludzi i rozwijanie ich kompetencji w tej dziedzinie (Liaisons sociales magazine, 2009).

Wśród materiałów mających podnieść świadomość uczniów w zakresie tworzenia i funkcjonowania firm właściwie nie było przystępnie opracowanych podręczników, a istniejące pomoce edukacyjne w większości miały charakter teoretyczny. Był to impuls do stworzenia nowych narzędzi, za pośrednictwem których młodzież szkolna mogłaby poznać ten temat. Do najciekawszych należą dwie publikacje szczególnie polecane przez Ministerstwo Edukacji: Lucy i Valentin... zakładaja firmę oraz Przedsiębiorstwo (wreszcie) objaśnione nastolatkom.

W pierwszej pozycji jej twórcy - studenci-przedsiębiorcy - sięgnęli po formułę komiksu, aby w zabawny a zarazem wciągający sposób pokazać młodym ludziom, jak wygląda tworzenie firmy od podstaw. Jak mówi główny pomysłodawca, Guilhem Bertholet: „W ramach AJEL (stowarzyszenie młodych przedsiębiorców z Lyonu) organizowaliśmy prelekcje w klasach ponadmaturalnych, żeby uwrażliwić młodych ludzi na punkcie zakładania firm. Zdaliśmy sobie sprawę, że praktycznie w ogóle ich to nie rusza. Podczas jednego z wystąpień zapytaliśmy, kto chciałby któregoś dnia otworzyć własną firmę. 80 osób na sali i ani jedna ręka nie poszła w górę... Dlatego stworzyliśmy ten komiks: żeby uświadomić młodym, że założenie firmy to taka sama droga kariery jak każda inna. [...] Początkowo miał być przeznaczony dla licealistów, 
ale potem uznaliśmy, że warto, aby zapoznali się z nim także uczniowie gimnazjów. Młodzież w tym wieku ma bardzo ograniczone postrzeganie przedsiębiorcy. Dla nich to starszy facet stojący na czele wielkiej firmy. Mają za mało wiadomości, tak naprawdę nie wiedzą co to znaczy być przedsiębiorcą" (Lucy et Valentin créent leur entreprise: une manière ludique de sensibiliser les jeunes, www.apce.com). Komiksowe perypetie młodych przedsiębiorców przeplatają się z dodatkowymi objaśnieniami każdego etapu zakładania firmy. Całość uzupełnia zestaw testów i ćwiczeń do przeprowadzenia na lekcjach.

Kolejną interesującą pozycją jest książka Bertranda Pointeau L'Entreprise (enfin) expliquée aux ados, czyli Przedsiębiorstwo (wreszcie) objaśnione nastolatkom. Jej autor, dyrektor francuskiego wydziału Bain \& Company - światowego giganta w dziedzinie konsultingu postawił sobie za cel w przystępny i rzeczowy sposób przedstawić młodzieży, ich rodzicom oraz nauczycielom świat przedsiębiorstw. Książka traktuje o wszystkich przedsiębiorstwach: małych i dużych, francuskich i zagranicznych, przemysłowych, handlowych i usługowych oraz opisuje w jasny sposób ich funkcjonowanie. Jak mówi autor: „Rozmawiamy czasem w domu o przedsiębiorstwie, o aktualnościach ze świata ekonomii. Moje dzieci ciekawią te tematy, ale zarazem podchodzą do nich nieufnie. Okazuje się, że ta tematyka jest dla nich mało przejrzysta. [...] Większość informacji dociera do nich poprzez mass-media, a one donoszą przede wszystkim o krachach finansowych, bankructwach, skandalach i konfliktach społecznych... Młodzieży brak podstawowych wiadomości, a przecież 70\% obecnych uczniów gimnazjów i liceów będzie w pewnym momencie swojego życia pracować w jakimś przedsiębiorstwie" (http://www.nathan.fr/entreprise-expliquee-aux-ados/). Pointeau przedstawia różne drogi kariery zawodowej pracowników i przedsiębiorców, kobiet i mężczyzn, z którymi młodzi ludzie mogą się utożsamiać. Treść przedstawiona jest obiektywnie, bez przejaskrawień, i ma na celu poprowadzić młodego człowieka ku refleksji nad jego przyszłą orientacją zawodową. Książka w prosty sposób, bez specjalistycznego żargonu, pokazuje na licznych, autentycznych przykładach, jak funkcjonuje przedsiębiorstwo i co stanowi o jego sukcesie lub porażce. Znalazło się w niej też miejsce na rozdziały poświęcone trwałemu rozwojowi, zawodom przyszłości oraz aktualnym tematom: etyce zawodowej, sprawiedliwości społecznej czy globalizacji.

Zarówno według uczniów, jak i nauczycieli korzystających z tych narzędzi i materiałów edukacyjnych zastosowane w nich metody aktywizujące oraz silne powiązanie treści nauczania z rzeczywistością gospodarczą pozwala w sposób atrakcyjny i praktyczny przygotować młodzież do odpowiedzialnego i zaplanowanego wejścia na rynek pracy.

\section{Podsumowanie}

Należy stwierdzić, że chociaż francuska oświata dość późno zorientowała się w usterkach systemu na linii szkoła - praca, podjęte zostały dość szeroko zakrojone, wszechstronne działania mające tę sytuację poprawić. Za wcześnie jeszcze, by oceniać, na ile reforma z 2005 r. okaże się skuteczna. Jednakże liczba oraz różnorodność działań i inicjatyw na rzecz zwiększenia świadomości ekonomicznej i postaw przedsiębiorczych wśród młodzieży oraz lepszego przygotowania jej do podjęcia pracy zawodowej daje dobry przykład innym krajom. Spośród przedstawionych działań na szczególne uznanie zasługują próby przełamania bariery pomiędzy szkołą a miejscem pracy lub uczelnią. Przenikanie się tych środowisk nie tylko wpływa na lepszą orientację wśród uczniów dokonujących wyboru drogi dalszego kształcenia, lecz również pozwala pracodawcom wpływać na działania w zakresie przygotowania do wyboru zawodu podejmowane przez szkołę. 


\section{Literatura \\ References}

Borowiec, M. (2009). Rola edukacji w kształtowaniu społeczeństwa informacyjnego. Przedsiębiorczość- Edukacja, 5, 37-47.

Czerepaniak-Walczak, M. (2001). Doradztwo w reformowanej szkole-gimnazjum jako ośrodek doradztwa. W: B. Wojtasik (red.), Podejmowanie decyzji zawodowych przez młodzież i osoby doroste w nowej rzeczywistości społeczno-politycznej. Wrocław: Instytut Pedagogiki Uniwersytetu Wrocławskiego, 345-360.

Diagnozowanie zapotrzebowania na kwalifikacje i umiejętności na lokalnych i regionalnych rynkach pracy. Ministerstwo Pracy i Polityki Społecznej. (2009). Warszawa.

Dorocki, S., Brzegowy, P. (2014a). Miejsce przedsiębiorczości w systemie edukacyjnym Francji i jej wpływ na aktywizację gospodarczą regionów. O idei l'esprit d'entreprise. Horyzonty wychowania, 13(26), 287-302.

Dorocki, S., Brzegowy, P. (2014b). Uwarunkowania przestrzennego zróżnicowania postaw przedsiębiorczych we Francji. Przedsiębiorczość - Edukacja, 10, 148-163.

Dument, L. (2009). Le travail raconté aux ados. Liaisons sociales magazine, Novembre.

Dziewulak, D. (2013). Doradztwo edukacyjno-zawodowe w szkolnictwie zawodowym w Polsce i w wybranych państwach Unii Europejskiej. Analizy, 4(93), 1-8.

Kilar, W., Kurek, S., Rachwał, T. (2013). Kształtowanie kompetencji osobistych i społecznych w szkolnictwie zawodowym dla sektora handlu detalicznego w świetle opinii partnerów społecznych. Przedsiębiorczość - Edukacja, 9, 273-288.

Kurek, S., Rachwał, T. (2011). Development of entrepreneurship in ageing populations of the European Union. Procedia. Social and Behavioral Science, 19, 397-405.

Kurek, S., Rachwał, T. (2010). The Role of Business Education in the Development of Entrepreneurship in the Member States of the European Union. Europa XXI, 19, Warszawa: PAN, 127-142.

Kurek, S., Rachwał, T., Szubert, M. (2012). Kształtowanie kompetencji biznesowych uczniów gimnazjum w świetle opinii nauczycieli na podstawie wyników badań prowadzonych w ramach europejskiego projektu FIFOBI. Przedsiębiorczość - Edukacja, 8, 24-36.

Naudé, W. (2008). Entrepreneurship in Economic Development. Research Paper 20. World Institute for Development Economics Research, 1-47.

Oleksiuk, A. (2013). Fenomen przedsiębiorczości akademickiej: mit czy rzeczywistość w perspektywie przyspieszenia rozwoju regionalnego w Europie?. Kwartalnik Naukowy Uczelni Vistula, 1(35), 73-92.

Piróg, D. (2005). Miejsce i rola edukacji europejskiej w nauczaniu podstaw przedsiębiorczości w kontekście współczesnych wyzwań cywilizacyjnych. Przedsiębiorczość - Edukacja, 1, 213-220.

Pointeau, B. (2008). L'Entreprise expliquée aux ados. Paris: Nathan.

Skup, M., Litwinowicz, A. (2011). Innowacyjne metody modernizacji oferty edukacyjnej na podstawie francuskich dobrych praktyk. Białystok: AR ADMIS.

Tadeusiewicz, G. (1997). Edukacja w Europie: szkoła, nauczyciel, doradztwo zawodowe. Łódź: PWN.

Wach, K. (2007). Kształtowanie postaw przedsiębiorczych w programach nauczania. Stan obecny i proponowane kierunki zmian. W: P. Wachowiak, M. Dąbrowski, B. Majewski (red.), Kształtowanie postaw przedsiębiorczych a edukacja ekonomiczna. Warszawa: Fundacja Promocji i Akredytacji Kierunków Ekonomicznych, 120-127.

Zioło, Z. (2012). Miejsce przedsiębiorczości w edukacji. Przedsiębiorczość - Edukacja, 8, 10-23.

\section{Źródla internetowe}

http://eduscol.education.fr/cid45784/option-facultative-ou-module-de-decouverte.html (2014, 21 października)

http://lucyetvalentin.com/ (2014, 23 października)

http://www.100000entrepreneurs.com/ (2014, 23 października)

http://www.ac-versailles.fr/public/jcms/p1_49625/decouverte-professionnelle-en-classe-de-troisieme (2014, 21 października) 
http://www.admission-postbac.fr/ (2014, 21 października)

http://www.apce.com/cid68781/lucy-et-valentin-creent-leur-entreprise-une-maniere-ludique-de-

sensibiliser-les-jeunes.html?pid=281 (2014, 23 października)

http://www.centre-info.fr

http://www.cereq.fr

http://www.cidj.com/article-metier/conseillere-conseiller-d-orientation-psychologue

http://www.education.gouv.fr/pid25535/bulletin_officiel.html?cid_bo=57114 Orientation active. Conseil

d'orientation anticipé pour la rentrée 2011 (2014, 21 października)

http://www.education.gouv.fr/cid1067/conseiller-d-orientation-psychologue-c.o.p..html

http://www.education.gouv.fr/cid157/la-decouverte-professionnelle-en-classe-de-troisieme.html (2014,

21 października)

http://www.education.gouv.fr/cid4717/orientation-active-pour-les-lyceens.html (2014, 21 października) http://www.education.gouv.fr/cid24356/parcours-decouverte-des-metiers-des-formations.html (2014, 21

października)

http://www.entreprendre-pour-apprendre.fr/ (2014, 23 października)

http://www.fondation-entreprendre.org/ (2014, 23 października)

http://www.france.fr/etudier-en-france/le-systeme-scolaire-francais-de-la-maternelle-au-lycee.html (2014,

19 października)

http://www.french.hku.hk/dcmScreen/lang2043/systeme_educatif.htm (2014, 19 października)

http://www.journaldunet.com/management/vie-personnelle/interview/bertrand-pointeau-l-entreprise-

expliquee-aux-ados-il-faut-sensibiliser-tres-tot-les-jeunes-aux-rouages-de-1-entreprise.shtml (2014,

21 października)

http://www www.koweziu.edu.pl

http://www.nathan.fr/entreprise-expliquee-aux-ados/ (2014, 23 października)

http://www.onisep.fr/Ressources/Univers-Metier/Metiers/conseiller-ere-d-orientation-psychologue

http://www.orientation-pour-tous.fr/metier/orientation-scolaire-et-professionnelle,12554.html

http://www.pole-emploi.fr/accueil/

Sławomir Dorocki, dr, absolwent studiów z zakresu geografii społeczno-ekonomicznej, doktor nauk humanistycznych w dyscyplinie historia (Instytut Europeistyki na Uniwersytecie Jagiellońskim). Adiunkt w Instytucie Geografii Uniwersytetu Pedagogicznego im. KEN w Krakowie. Zainteresowania badawcze autora skupiają się wokół problematyki regionów i procesów regionalizacji społeczno-gospodarczej, ze szczególnym uwzględnieniem zróżnicowania przestrzeni europejskiej oraz procesów integracji europejskiej i uwarunkowań historycznych.

Sławomir Dorocki, graduated from Pedagogical University in Krakow MS degree in geography, PhD. in history (Institute of European Studies of the Jagiellonian University). Adiunkt (assoc. professor) at Pedagogical University of Cracow, Institute of Geography. His research interests are tied with regional problems and processes of socio-economic regionalization, with particular emphasis on the diversity of Europe, processes of European integration and historical conditions.

Adres/Address: Uniwersytet Pedagogiczny im. Komisji Edukacji Narodowej w Krakowie Instytut Geografii Zakład Przedsiębiorczości i Gospodarki Przestrzennej

ul. Podchorążych 2

30-084 Kraków, Polska

e-mail: sdorocki@up.krakow.pl 
Marek Ziarko, mgr, absolwent filologii romańskiej na Uniwersytecie Pedagogicznym im. KEN w Krakowie. Studia podyplomowe "Diplôme d’Études Supérieures Spécialisées, Certificat d'Aptitude à l'Administration des Entreprises" na Université Lille. Studia podyplomowe na kierunku geografia na Uniwersytecie Pedagogicznym im. KEN w Krakowie. Nauczyciel języka francuskiego i geografii. Zainteresowania autora: zagraniczna literatura geograficzna ze szczególnym uwzględnieniem krajów romańskich, historia myśli geograficznej.

Marek Ziarko, M.A. - Secondary and Vocational School Complex in Świątniki Górne, graduate of the Faculty of Romance Philology at the Pedagogical University of Cracow. Postgraduate course "Diplôme d'Études Supérieures Spécialisées, Certificat d'Aptitude à l'Administration des Entreprises" at Lille University. Postgraduate course in geography at the Pedagogical University of Cracow. Teacher of French and geography. Interests: foreign literature on geography with a special emphasis on the romance countries, history of the geographical thought.

Adres/Address: Zespół Szkół w Świątnikach Górnych

ul. Bruchnalskiego 35

32-040 Świątniki Górne, Polska

e-mail: marekziarko@interia.pl

Rose Boutron, nauczycielka, koordynatorka UNESCO w Gimnazjum Robert Goupil w Beaugency. Wykładowczyni języka francuskiego z opcją découverte professionnelle (odkrywanie zawodów).

Rose Boutron, professeur, coordinatrice UNESCO pour le collège Robert Goupil de Beaugency. Enseignante du français avec l'option "découverte professionnelle".

Adres/Address: Le collège Robert Goupil

4, rue de la Croix Nas

45190 Beaugency, Francja

e-mail: rose.boutron@wanadoo.fr 